\title{
Climate Change and Children's Health-A Call for Research on What Works to Protect Children
}

\author{
Zhiwei Xu ${ }^{1}$, Perry E. Sheffield ${ }^{2}$, Wenbiao Hu ${ }^{3}$, Hong Su ${ }^{4}$, Weiwei Yu ${ }^{1}$, Xin Qi ${ }^{1}$ and \\ Shilu Tong ${ }^{1, *}$
}

1 School of Public Health \& Institute of Health and Biomedical Innovation, Queensland University of Technology, Kelvin Grove, Brisbane, QLD 4059, Australia;

E-Mails: xu.zhiwei@student.qut.edu.au (Z.X.); weiwei.yu@qut.edu.au (W.Y.);

xin.qi@student.qut.edu.au (X.Q.)

2 Department of Preventive Medicine and Pediatrics, Mount Sinai School of Medicine, New York, NY 10029, USA; E-Mail: perry.sheffield@mssm.edu

3 School of Population Health, University of Queensland, Brisbane, QLD 4066, Australia;

E-Mail:w.hu@sph.uq.edu.au

4 Department of Health Statistics and Epidemiology, School of Public Health, Anhui Medical

University, Hefei 230032, China; E-Mail: suhong5151@sina.com

* Author to whom correspondence should be addressed; E-Mail: s.tong@qut.edu.au;

Tel: +61-7-3138-9745; Fax: +61-7-3138-3369.

Received: 18 July 2012; in revised form: 15 August 2012 / Accepted: 5 September 2012 /

Published: 10 September 2012

\begin{abstract}
Climate change is affecting and will increasingly influence human health and wellbeing. Children are particularly vulnerable to the impact of climate change. An extensive literature review regarding the impact of climate change on children's health was conducted in April 2012 by searching electronic databases PubMed, Scopus, ProQuest, ScienceDirect, and Web of Science, as well as relevant websites, such as IPCC and WHO. Climate change affects children's health through increased air pollution, more weather-related disasters, more frequent and intense heat waves, decreased water quality and quantity, food shortage and greater exposure to toxicants. As a result, children experience greater risk of mental disorders, malnutrition, infectious diseases, allergic diseases and respiratory diseases. Mitigation measures like reducing carbon pollution emissions, and adaptation measures such as early warning systems and post-disaster counseling are strongly needed. Future health research directions should focus on:
\end{abstract}


(1) identifying whether climate change impacts on children will be modified by gender, age and socioeconomic status; (2) refining outcome measures of children's vulnerability to climate change; (3) projecting children's disease burden under climate change scenarios; (4) exploring children's disease burden related to climate change in low-income countries; and (5) identifying the most cost-effective mitigation and adaptation actions from a children's health perspective.

Keywords: climate change; child health; mechanism; mitigation; adaptation

\section{Introduction}

Human-induced climate change is one of the biggest social, environmental and public health challenges we face in this century [1]. Groups such as children, the elderly and people with low socioeconomic status are particularly vulnerable to the effects resulting from such change [2]. Climate change poses a significant threat to children's health because children have unique metabolism, behavior, physiology and development characteristics [3]. Many of the main killers of children (e.g., malaria, diarrheal disease and malnutrition) are very sensitive to climatic conditions and they are expected to worsen as a result of climate change. Changes in the spectrum of vector-borne diseases, and increasing air pollution from the continued burning of fossil fuels also threaten children's health, quality of life, access to education and overall development [2]. Stern et al. reported that climate change could cause an additional 40,000 to 160,000 children's deaths per year in South Asia and sub-Saharan Africa through gross domestic product losses alone, under a baseline climate change scenario. Under a high climate change scenario, this projection increases to an additional 60,000 to 250,000 children's deaths per year by 2100 [4]. The World Health Organization (WHO) estimated that climate change contributed to more than 150,000 deaths and 5.5 million lost disability-adjusted life years worldwide, in 2000 alone [5], and more than $88 \%$ of this burden occurs in children under the age of five years [6,7].

Compared with adults, children breathe more air, drink more water, and eat more food per unit of body weight [8]. They often play outdoors, and are expected to live longer than adults, exposing them to newly developing or worsening environmental hazards in the future. Additionally, many diseases have a long latency period, sometimes requiring decades to develop. Their hand to mouth behaviour, and the fact that they live and play close to the ground further increases children's exposure to environmental hazards [9]. There has been increasing interest in climate change's impact on children's health [10]. Though warming in cold regions may have some beneficial effects on children (e.g., reducing some cold-related deaths and diseases, such as viral diarrheal and respiratory infections), the negative impacts of climate change on children may far outweigh the positive effects. Previous reviews have all noted children's potential increased vulnerability to climate change but there has been little discussion on the mechanisms of such vulnerability. In this article, we sought to articulate the mechanisms of children's vulnerability to climate change (Table 1), and elucidate knowledge gaps in the existing literature. We further make some recommendations on research directions in this important field. The most common strategies to tackle climate change include mitigation and adaptation. Failure to 
mitigate will finally lead to the failure of adaptation because the magnitude of the impacts is predicted to become too large to manage even with considerable investment [11]. In this review, we also discuss mitigation and adaptation strategies for preventing children from being harmed by climate change in the future.

Table 1. Impact of climate change on children's health.

\begin{tabular}{|c|c|c|}
\hline Impacts & Exposures & Outcomes \\
\hline \multirow{4}{*}{$\begin{array}{c}\text { Direct } \\
\text { impacts }\end{array}$} & Air pollution & $\begin{array}{l}\text { Decreased lung function } \\
\text { Lung cancer } \\
\text { Asthma } \\
\text { Birth defects } \\
\text { Other respiratory disease } \\
\text { Mortality } \\
\end{array}$ \\
\hline & Floods & $\begin{array}{c}\text { Drowning } \\
\text { Injury } \\
\text { Physical and mental trauma } \\
\text { Children neglect or abuse } \\
\end{array}$ \\
\hline & Droughts & $\begin{array}{c}\text { Mental disorders } \\
\text { Infant deaths } \\
\end{array}$ \\
\hline & Heat waves & $\begin{array}{c}\text { Renal disease } \\
\text { Respiratory disease } \\
\text { Electrolyte imbalance } \\
\text { Fever } \\
\text { Possible birth defects } \\
\end{array}$ \\
\hline \multirow{6}{*}{$\begin{array}{l}\text { Indirect } \\
\text { impacts }\end{array}$} & Decreased water & $\begin{array}{c}\text { Respiratory disease } \\
\text { Diarrhea }\end{array}$ \\
\hline & Toxicant exposure & $\begin{array}{c}\text { Reproductive disorder } \\
\text { Immune dysfunction } \\
\text { Neural System dysfunction } \\
\text { Cancer } \\
\end{array}$ \\
\hline & Food shortage & $\begin{array}{c}\text { Malnutrition } \\
\text { Mortality } \\
\end{array}$ \\
\hline & $\begin{array}{c}\text { Population } \\
\text { displacement }\end{array}$ & $\begin{array}{c}\text { Disrupting health care } \\
\text { Loss of education }\end{array}$ \\
\hline & \multicolumn{2}{|c|}{ Allergic disease } \\
\hline & & us disease \\
\hline
\end{tabular}

\section{Methods}

An extensive literature review was conducted in April 2012 using electronic databases PubMed, Scopus, ProQuest, ScienceDirect, and Web of Science. Additionally, relevant websites, such as IPCC and WHO, were also searched. Our primary search used the following U.S. National Library of Medicine's Medical Subject Headings (MeSH terms) and keywords: climate change, child health, risk, response, mitigation and adaptation. Relevant empirical studies, review papers and organizational 
reports written in English which were published up to 1 April 2012 were included in the final assessment. Eligibility included papers or documents which considered climate change, direct and indirect environmental hazards (heat wave, weather-related disasters, and contaminated water etc.) resulting from climate change as the major exposure, and where children's health was considered as one of the major outcome of interest.

\section{Results and Discussion}

We identified 1,935 scholarly papers and government and official publications in the initial search. Among which, 1,898 were primary or review papers. We firstly read the title of the 1,935 documents, and excluded 1,519 of them because of the non-relevant titles. Secondly, we read the abstracts of the remaining literature and excluded 313 of them as they did not meet the inclusion criteria. Thirdly, we read the full texts of the remaining documents and excluded 11 of them because children's health were not specifically considered as outcome in these studies. Nine documents were added after manually inspecting the reference lists of all relevant documents. Finally, 101 documents were included. Among the remaining 101 documents, 61 were primary research, 15 were reviews, and 25 were government and official publications.

\subsection{Direct Impact}

\subsubsection{Air Pollution}

Air pollution is closely associated with climate change and is expected to worsen as climate change continues [12]. Climate change will affect future air quality through perturbing ventilation rates, precipitation scavenging, dry deposition, chemical production and loss rates, natural emissions, and background concentrations [13]. Climate change related wildfires could be an important source of particular matter [13]. Chang et al. projected the impact of climate change on ozone concentration and found that the average ozone concentration will increase by $0.43 \mathrm{ppb}$ during the 2040s compared to 2000 due to climate change [14].

Children, together with elderly, represent subpopulations particularly sensitive to the negative health effects of air pollution [15]. Their exposure to outdoor particulate matter has been associated with respiratory symptoms, decreased lung function, worsening of asthma and the development of chronic bronchitis [8,16-22]. Ozone exposure may also render a number of adverse health effects in children, including shortness of breath, wheezing and coughing, temporary decreases in lung function, and lower respiratory tract infections [8,23]. Climate change negatively impacts indoor air quality too [24]. Indoor air pollution is responsible for the deaths of an estimated 1.6 million people annually, and more than half of these deaths occur among children under age five [25]. Biomass fuels use was associated with acute respiratory infections, lung cancer, tuberculosis, asthma and blindness in India. Smith found that indoor air pollution caused 4-6 per cent of the Indian national burden of disease by using a disability-adjusted life-year lost approach [26]. 


\subsubsection{Weather-Related Disasters}

Climate change will increase the frequency and intensity of floods, droughts, bushfires and cyclones [27]. 66.5 million children, 600,000 of whom died, were affected by weather-related disasters every year from 1990 through 2000 [28]. Some studies have argued that children have more persistent symptoms of mental health impairment than adults who experience the same disaster [29]. Exposure to natural disasters was reported to exacerbate the burden of depression, anxiety and stress [30]. High rates of sleep disturbance, sadness, and other mental health impairments among children are associated with weather-related disasters [31]. In addition, high stress for adults after weather-related disasters can have serious implications for children, by impeding the adults' ability as caregivers and in extreme circumstances resulting in neglect and even abuse [32,33].

Globally, floods are the most frequent weather-related disaster, accounting for $43 \%$ of all disasters between 1993 and 2001 [34]. Severe flooding in Nepal illustrated that the flood-related fatality rates for children were six times higher than mortality rates in the same villages a year before the flood [35]. In many areas of the world, drowning is a leading cause of death among young children [36], especially for boys 5 to 14 years of age [37]. Some of the effects can differentially impact girls. Indian women born during a flood in the 1970s were 19 percent less likely than men born at the same time to have attended primary school [38]. Extreme floods also led to an increase in the number of girls who were displaced from rural areas and became sex-workers in Bangladesh [39].

Droughts exacerbate desertification, which threatens agricultural production in most of African countries [40]. Desertification is associated with food and water insecurity, malnutrition and elevated infant mortality. In some regions, droughts and their associated famines are the most deadly weatherrelated disasters [41]. Children aged under six years in Ethiopia and Kenya who were born during a drought were more likely to be malnourished than those born in non-drought years. Children less than three years of age who were born in Niger in drought years were more likely to be stunted than those born in non-drought years [38]. Further, severe droughts were associated with vitamin A deficiencies in rural pre-school children in India [42].

\subsubsection{Heat Waves}

Heat waves, sporadic periods of elevated temperatures outside the normal range of climate variability, occur throughout the world and are projected to become more frequent and intense in the future [43]. Studies in various countries have reported that children, especially very young children, are particularly vulnerable to heat waves [44-46]. Children's renal disease is an important consequence of heat waves [46]. Exposure to extreme hot weather can induce heat-related conditions including hyperthermia and heat stress in children [47], and the renal system can be stressed or compromised by a suite of reflexive thermoregulatory, physiological, and circulatory adjustments. Respiratory diseases also increase among children during heat wave periods [48]. Knowlton and colleagues found that emergency department visits for electrolyte imbalance and heat-related illnesses increased during the 2006 California heat event among the 0-4 year age group [44]. They also assessed the impact of heat waves on hospital admissions for electrolyte imbalance, heat-related illnesses, acute renal failure and nephritis, but have not found significant effects [44]. A large increase 
in the number of calls for fever to National Health Service-a nurse-led helpline which provides health-related information, was seen for children 0-4 years in Greater London and South East regions of UK during a heat wave period [45]. Previous studies have reported the effect of temperature on adverse birth outcomes [49,50], which indicates that maternal exposure to heat waves may negatively influence children's birth outcomes, even though there is no study specifically focusing on the impact of heat waves on birth outcomes to date. Some researchers reported that the adverse effects of heat waves were mainly due to the independent effects of hot temperature rather than the sustained duration of heat [51,52].

\subsection{Indirect Impacts}

Climate change is threatening a number of fragile ecosystems [19,53,54]. Children's health depends on the continuous supply of various ecological services— "the conditions and processes through which natural ecosystems, and the species that make them up, sustain and fulfill human life” [55], and ecological services are underpinned by biodiversity which is also threatened by a number of climate change mechanisms. In addition rising sea levels and inundation of coastal areas, exacerbated by climate change, could render major disruption of social systems.

\subsubsection{Decreased Water Quality and Quantity}

Climate change alters the hydrologic cycle, melting sea ice, accelerating evaporation from sea and other surface waters, increasing the frequency and intensity of precipitation in some areas, and triggering drought in other areas [56]. Ground and surface water supplies can run short because of drought, and rising sea levels can cause salt water intrusion into groundwater. Storms and floods can compromise supplies of clean water [57,58]. As the temperatures rise, the replication of the pathogens which water carries (protozoa, bacteria and viruses) will also increase [59]. Contaminated water is the major cause of malnutrition and diarrheal disease, which remain a leading cause of death in children under five years of age [60].

\subsubsection{Food Supply Shortage}

Increased evaporation dehydrates soils, and flooding salinates other arable land, diminishing agricultural area and productivity [61]. Children require three or four times more food per unit of body weight than adults and comprise the majority of the global population plagued by hunger [62,63]. Declining food production and rising food prices will exacerbate the global rates of malnutrition and stunting, and further threatening children's health [64]. Some adverse effects of food supply shortages occurring in low- and middle-income countries extend beyond hunger and malnutrition. For example, many of Bombay's young prostitutes are from poor rural villages in Nepal, where inadequate crop yields cause families to sacrifice one child so others may survive [65].

\subsubsection{Toxicant Exposure}

As climate change continues, temperature, humidity and hydrologic cycles change, and the distribution of environmental toxicants change subsequently [66,67]. Increased precipitation and 
ice/snow melt in some areas may enhance wet deposition of persistent organic pollutants to aquatic and terrestrial ecosystems [68-70]. Regions of decreased precipitation might experience more volatilization of persistent organic pollutants and pesticides to the atmosphere.

Rising temperature will enhance the toxicity of contaminants and increase concentrations of tropospheric ozone regionally [71]. Consequently, children may experience greater exposure to toxic substances. Exposure to a wide range of chemicals and environmental toxicants during childhood, especially chemical neurotoxicants, may affect the development, maturation, growth and function of organ systems of children [72-75]. Children are particularly vulnerable to the neurotoxic effects of lead: low levels of exposure can reduce intelligence quotient scores, and cause learning disabilities [76,77]. Methylmercury exposure is also a health hazard to the fetus in population groups that consume contaminated fish [78]. Exposure to persistent organic pollutants during early life stages may result in effects in later life [79,80].

\subsubsection{Population Displacement}

Drought and severe floods are already forcing people to move more frequently [81]. Such displacement can have serious consequences for children, including fragmenting families and disrupting social networks. Disease outbreaks are more common in displaced communities [82,83]. There is some evidence that underlying chronic conditions or latent infections (such as tuberculosis) may be more likely to occur when people move into a new environment [84].

\subsubsection{Infectious Diseases}

Climate change may influence the replication rates, survival and transmission of infectious disease pathogens [34]. Storms and floods may result in crop contamination and drinking water contamination which leads to illness [34]. Compared with adults, children consume a larger relative proportion of fruits and vegetables and spend a larger proportion of time outdoors, increasing climate-sensitive exposures such as pesticide residues on food and outdoor insect vectors [85]. Their relatively naive immune systems increase the risk of serious consequences from water- and food-borne diseases [86]. Every year, waterborne diseases such as cholera and other diarrheal diseases cause deaths of millions of children in the developing world, a number that will likely increase as climate changes [39].

Increasing temperatures, changing precipitation, and shifting climate variability may change the distribution of vector-borne infectious diseases by affecting the hosts (e.g., rodents, insects and snails) and the pathogens (e.g., bacteria, viruses and parasites) [87-89]. Children are especially prone to mosquito and tick bites because of often playing outside and close to the ground, where these insects gather [90]. In some regions of sub-Saharan Africa, the death rate from malaria in children aged 0 to 4 years is much greater than the death rate in the population aged over 14 years old [91,92]. A wide range of vector-borne diseases can affect young children in particular, the major health risk threats being malaria, schistosomiasis, Japanese encephalitis, and dengue hemorrhagic fever. Children, especially infants, are still in the process of physiological growth, and they are immunologically sensitive to some infectious disease pathogens [93]. If not fatal, infectious diseases can still have disabling consequences such as increased risk of hearing loss or other neurologic decrements following meningitis—a climate sensitive disease in a large swath of Africa [94]. 


\subsubsection{Allergic Diseases}

Childhood asthma is a widespread health problem because of its epidemic prevalence [95]. Although the prevalence of childhood asthma decreased in some countries during recent years, such as Australia, it increased in a variety of countries [96]. Climate change is associated with changes in aeroallergens [97]. Pollen counts could rise due to multiple mechanisms such as increased ambient $\mathrm{CO}_{2}$ levels [98], increased temperature, or earlier spring seasons [99]. Elevated $\mathrm{CO}_{2}$ concentration often increases plant leaf biomass and carbon-to-nitrogen ratio which can affect not only pollen but also mold. Elevated ambient $\mathrm{CO}_{2}$ levels are associated with increased fungal spore production, a potential other asthma trigger [100]. Increased temperature can also affect spatial distribution and density of plants and fungi that produce aeroallergens [101]. Allergic disease will also likely be worsened because of interaction between climate change impacts on thunderstorms which can fractionate pollen into smaller particles; extreme precipitation events; and increasing heat-related ground-level ozone pollution [102]. The current global increase in childhood asthma can be partly explained by increased exposure to aeroallergens driven by climate change [103].

\subsection{Mitigation and Adaptation Strategies for Children}

Mitigation mainly includes technical and infrastructural investments, renewable energy implementation, and improving energy efficiency-all with the singular goal of reducing carbon pollution. While there are many sectors that contribute to carbon pollution, the transport sector is projected to have the fastest proportional growth in carbon pollution of any sector from 1990-2020 [104]. Promoting public transport use will be beneficial for rapidly reducing. Improving building energy efficiency, especially in places like India where two-thirds of the high-rise building stock is projected to be constructed over the coming decades, is also an important means of climate mitigation [105]. Increasing the urban tree canopy can also reduce carbon dioxide produced by fuel combustion [106]. At the individual level, some measures can be adopted such as the trifecta of reduce, reuse, and recycle as means of also increasing energy efficiency. Young athletes are more likely to be involved in outdoor activities, and their external thermal load is largely dependent on climate factors, including ambient temperature, humidity and solar radiation [107]. A variety of protective measures implemented by the local governments, such as providing air-conditioned meeting rooms and locker rooms for athletes, as well as cooling stations on or immediately next to the competition site, will be helpful for preventing athletes from heat-related health risks.

Different from mitigation which will likely ultimately necessitate wide multinational accords, adaptation is better to be implemented at the local level [108]. Currently, report on specific adaptation measures for children is limited [109]. Sustainable economic development, reduction of poverty and wealth disparity, and improvement in baseline health, food security and education are fundamentally the best form of climate change adaptation. In terms of tackling natural disasters more specifically, effective awareness programmes in schools, homes and communities can contribute to the capacity of nations and communities where resources are limited to help children during disasters [110]. Post-disaster counseling can reduce the medium- and long-term mental health burden on children significantly [111,112]. Activation of early warning systems before heat waves is considered as a useful children-protective measure in handling heat wave hazards [7]. Childhood immunization 
programmes, drinking water disinfection, source water protection and sanitation are all necessary actions which protect children from possible adverse impacts of ecological change. Pediatricians can play important roles as advocates by individual example and through community participation to address the effects of climate change to create a healthier world for children worldwide [113,114].

\subsection{Knowledge Gaps}

Existing research gives strong evidence that climate change is influencing and will increasingly affect children's health. Nevertheless, substantial information gaps remain regarding the risk climate change poses to children's health and child-specific protection measures.

\subsubsection{The Modifiers}

Children are already known as a particularly vulnerable group to climate change, but: (1) what social factors are already in place that are potentially protective (e.g., caregiver behavior, school attendance, etc.)? and (2) what else can we do to protect children besides slowing climate change? is still unknown. Previous studies looking at the impact of climate change (e.g., temperature extremes) on human well-being tend to consider children under 15 years old as a whole [115], or group them such as 0-4 and 5-14 years old [46]. In fact, children are heterogeneous both physiologically and behaviorally, not all of them are equally at the same risk. Children under 1 year old are likely to be more sensitive to heat waves because of their extremely poor self-care ability and immature regulation systems [116], and children aged 5-14 years may be more exposed to air pollution because they are engage in outdoor activities more frequently $[117,118]$. And as such, considering children of different age groups and estimating their vulnerability to climate change hazards would be beneficial for developing targeted protection strategies.

Similar to age, the role of school attendance in modifying the effect of climate change on children still remains to be understood, though some studies have touched a bit on this issue. Regular attendance at school is essential for children's education and social skills, and prolonged non-attendance was associated with social isolation [119]. Globally, the proportion of children attending school varies widely particularly for secondary school attendance which is as high as approximately $90 \%$ in some high-income regions [120] and lower than 50\% in some low-income regions [121]. Existing studies indicate the possible protective or risky effects of school attendance on the occurrence of different pediatric diseases known to be sensitive to climate factors. Checkley et al. revealed that school absence may affect the incidence of pediatric diarrhea [122]. Grech et al. found that the end of school was associated with a drop in pediatric asthma admission, and restarting school correlated with a sharp rise [123]. Nevertheless, to date, no study specifically examines whether school attendance protects children from being affected by climate change hazards.

Besides school attendance, sports participation may also modify the impact of climate change on children's health, because the exertion related to playing sports put children at an increased risk of being exposed to heat and air pollution [124,125]. The possible modifying effects of other factors, including gender, caregiver behavior, air conditioning use [126], nutritional status and vaccination status [127], also need elucidating as climate change continues. 


\subsubsection{The Appropriate Outcome Measures}

Existing studies tend to use mortality and morbidity as the measures of the climate change impact, including total- and cause-specific mortality [128], hospital admissions [46] and emergency department visits [129]. Meanwhile, they were likely to treat deaths amongst children, adults and elderly as equally important. However, if most deaths were in the very elderly, who had only a life expectancy of a few years, the burden of climate change on human well-being would have less public health importance [130]. Using mortality and morbidity as outcome measures may underestimate the impact of climate change on children. Years of life lost (YLL) is an indicator of premature mortality that accounts for the age at which deaths occurred by giving greater weight to deaths at younger ages [131], and it might be a more appropriate measure to evaluate the impact of climate change on human health because of emphasizing the influence of early deaths on disease burden. Years of life lived with disability (YLD) takes into account disease duration, age at onset, and a disability weight reflecting the severity of disease [132]. The disease onset at very young age is more likely to cause larger years of life lived with disability when compared with onset at older age. Besides the aforementioned outcome measures, some other adverse consequences of climate change in children, such as loss of education, should also be considered, even though few studies to date have mentioned this [133].

\subsubsection{Children’s Disease Burden under Climate Change Scenarios}

Extensive studies have estimated the existing impact of climate change on children's health $[134,135]$, and some researchers have projected the future influence of specific climate change hazards on the total population [136,137], but no study focuses on the projection of children's disease burden under future climate change scenarios. Despite existing uncertainty, the potential exists to begin to estimate how climate change will affect children with respect to mortality and morbidity in the future. Questions to explore include: how will infectious disease in children be influenced by climate change and to what extent will climate change affect chronic disease burden of children?

\subsubsection{The Situations in Low-Income Countries}

In high-income countries, people aged under 18 years old constitute approximately 20 percent of the total population, but in some low-income countries universally considered more vulnerable to climate change, this young age group represents nearly 50 percent of the population [138]. Additionally, mortality rates of children under 5 are lower than crude mortality rates in some wealthy countries. However, under 5 mortality rates are much higher than adults in some poor countries [138]. Most studies regarding the impact of climate change hazards on children have been conducted in high-income or middle-income countries. Hajat et al. found that a high proportion of Delhi deaths (48\%) during periods of high ambient temperatures occurred among children younger than 15 years old, which was much higher than the proportion in São Paulo (10\%), which in turn was substantially greater than the proportion in London (1\%) [115]. This finding indicates that children in low-income countries may experience greater climate change-related health risks than those in developed countries, but this area also need further investigation. 


\subsubsection{The Most Cost-Effective Mitigation and Adaptation Strategies for Children}

Currently, climate change mitigation and adaptation measures tailored for children are limited. Children should be the focus of climate change strategy planning process, which can be carried out in three stages. Firstly, the potential impacts of climate change on children should be documented. Secondly, children's health ought to be a major focus of the planning process for either mitigation or adaptation activities. The needs and ideas to protect children's health must be considered in this stage. Thirdly, once the plans are completed and being carried out, they should be tested to ensure that they are sufficient to address children's health. Formulating acceptable adaptation measures for children as well as implementing cost-effectiveness analysis of these measures will not only improve the quality of adaptation efforts but also be beneficial for future climate change mitigation efforts. In the process of developing mitigation and adaptation strategies specifically focusing on children, the socioeconomic and some other characteristics of each target region should be taken in to account because different mitigation and adaptation strategies may be needed for different locations.

\section{Conclusions}

Because of multiple age-specific characteristics, children are uniquely vulnerable to climate change. Despite some research has been done on evaluating the impacts of climate change on children's health, more works in this field are urgently needed. Future health research directions should focus on: (1) How climate change impacts on children will be modified by gender, age and socioeconomic status; (2) what are the most appropriate outcome measures of children's vulnerability to climate change; (3) how to project children's disease burden under climate change scenarios; (4) what is the situation about children's disease burden related to climate change in low-income countries; and (5) what are the specific mitigation and adaptation actions that are most cost-effective from a children's health perspective.

\section{Acknowledgements}

We would like to thank Yuming Guo and Cunrui Huang for their valuable comments on the early draft. Zhiwei $\mathrm{Xu}$ was funded by a China Scholarship Council Postgraduate Scholarship and Queensland University of Technology fee waiving scholarship; Shilu Tong was supported by a National Health and Medical Research Council Research Fellowship (\#553043).

\section{Conflict of Interest}

The authors declare no conflict of interest.

\section{References}

1. IPCC. Summary for Policymakers. In Climate Change 2007: The Physical Science Basis. Contribution of Working Group I to the Fourth Assessment Report of the Intergovernmental Panel on Climate Change; Cambridge University Press: Cambridge, UK, 2007. 
2. UNICEF. Climate Change and Children: A Human Security Challenge; Hellenic Foundation for European and Foreign Policy, UNICEF and UNICEF Innocenti Research Centre: New York, NY, USA, 2008.

3. Bunyavanich, S.; Landrigan, C.P.; McMichael, A.J.; Epstein, P.R. The impact of climate change on child health. Ambul. Pediatr. 2003, 3, 44-52.

4. The Economics of Climate Change: The Stern Review; Cambridge University Press: Cambridge, UK, 2007.

5. McMichael, A.; Butler, C. Climate change, health, and development goals. Lancet 2004, 364, 2004-2006.

6. Patz, J.A.; Campbell-Lendrum, D.; Holloway, T.; Foley, J.A. Impact of regional climate change on human health. Nature 2005, 438, 310-317.

7. Sheffield, P.E.; Landrigan, P.J. Global climate change and children's health: Threats and strategies for prevention. Environ. Health Perspect. 2010, 119, 291-298.

8. Committee on Environmental Health. Ambient air pollution: Health hazards to children. Pediatrics 2004, 114, 1699-1707.

9. Landrigan, P.; Garg, A. Children are not little adults. In Children's Health and the Environment-A Global Perspective; WHO: Geneva, Switzerland, 2005.

10. Akachi, Y.; Goodman, D.; Parker, D. Global Climate Change and Child Health: A Review of Pathways, Impacts and Measures to Improve the Evidence Base; UNICEF: New York, NY, USA, 2009.

11. McKibbin, W.J.; Wilcoxen, P.J. Climate policy and uncertainty: The roles of adaptation versus mitigation. In Brookings Discussion Papers in International Economics; The Brookings Institution: Washington, DC, USA, 2004.

12. IPCC. "Human Health" in Climate Change 2007: Impacts, Adaptation and Vulnerability, Contribution of Working Group II to the Fourth Assessment Report of the IPCC; IPCC: Geneva, Switzerland, 2007.

13. Jacob, D.; Winner, D. Effect of climate change on air quality. Atmos. Environ. 2009, 43, 51-63.

14. Chang, H.H.; Zhou, J.; Fuentes, M. Impact of climate change on ambient ozone level and mortality in southeastern United States. Int. J. Environ. Res. Public Health 2010, 7, 2866-2880.

15. Mathieu-Nolf, M. Poisons in the air: A cause of chronic disease in children. J. Toxicol. Clin. Toxicol. 2002, 40, 483-491.

16. U.S. Environmental Protection Agency (US EPA). Particle Pollution and Your Health; Volume EPA-452/F-03-001; US EPA: Washington, DC, USA, 2003.

17. Gauderman, W.J.; Avol, E.; Gilliland, F.; Vora, H.; Thomas, D.; Berhane, K.; McConnell, R.; Kuenzli, N.; Lurmann, F.; Rappaport, E.; et al. The effect of air pollution on lung development from 10 to 18 years of age. N. Engl. J. Med. 2004, 351, 1057-1067.

18. Rodriguez, C.; Tonkin, R.; Heyworth, J.; Kusel, M.; De Klerk, N.; Sly, P.D.; Franklin, P.; Runnion, T.; Blockley, A.; Landau, L.; et al. The relationship between outdoor air quality and respiratory symptoms in young children. Int. J. Environ. Res. Public Health 2007, 17, 351-360.

19. Shea, K.; American Academy of Pediatrics Committee on Environmental Health. Global climate change and children's health. Pediatrics 2007, 120, 1149-1152. 
20. U.S. Environmental Protection Agency (US EPA). Health Effects of Wood Smoke; US EPA: Washington, DC, USA, 2008.

21. U.S. Environmental Protection Agency (US EPA); National Center for Environmental Assessment-RTP Division. Integrated Science Assessment for Particulate Matter: First External Review Draft; US EPA: Washington, DC, USA, 2008.

22. Sheffield, P.E.; Knowlton, K.; Carr, J.L.; Kinney, P.L. Modeling of regional climate change effects on ground-level ozone and childhood asthma. Am. J. Prev. Med. 2011, 41, 251-257.

23. U.S. Environmental Protection Agency (US EPA). Ozone: Good up High, Bad Nearby; Volume EPA-451/K-03-001; US EPA: Washington, DC, USA, 2003.

24. Committee on the Effect of Climate Change on Indoor Air Quality and Public Health, Institute of Medicine. Climate Change, the Indoor Environment, and Health; The National Academies Press: Washington, DC, USA, 2011.

25. WHO. Indoor Air Pollution and Household Energy. Available online: http://www.who.int/heli/ risks/indoorair/indoorair/en/index.html (accessed on 5 September 2012).

26. Smith, K.R. National burden of disease in India from indoor air pollution. Proc. Natl. Acad. Sci. USA 2000, 97, 13286-13293.

27. Schiermeier, Q. Climate and weather: Extreme measures. Nature 2011, 477, 148-149.

28. Pronczuk, J.; Surdu, S. Children's environmental health in the twenty-first century. Ann. N. Y. Acad. Sci. 2008, 1140, 143-154.

29. Shaw, J.A.; Applegate, B.; Schorr, C. Twenty-one month follow-up study of school-age children exposed to hurricane Andrew. J. Am. Acad. Child. Psychiatry 1996, 35, 359-364.

30. Kar, N.; Mohapatra, P.K.; Nayak, K.C.; Pattanaik, P.; Swain, S.P.; Kar, H.C. Post-traumatic stress disorder in children and adolescents one year after a super-cyclone in Orissa, India: Exploring cross-cultural validity and vulnerability factors. BMC Psychiatry 2007, 7, doi:10.1186/ 1471-244X-7-8.

31. Ahern, M.; Kovats, R.S.; Wilkinson, P.; Few, R.; Matthies, F. Global health impacts of floods: Epidemiologic evidence. Epidemiol. Rev. 2005, 27, 36-46.

32. Curtis, T.; Miller, B.C.; Berry, E.H. Changes in reports and incidence of child abuse following natural disasters. Child. Abuse Negl. 2000, 24, 1151-1162.

33. Keenan, H.T.; Marshall, S.W.; Nocera, M.A.; Runyan, D.K. Increased incidence of inflicted traumatic brain injury in children after a natural disaster. Am. J. Prev. Med. 2004, 26, 189-193.

34. U.S. Environmental Protection Agency (US EPA). Climate Change and the Health of Children. Available online: http://yosemite.Epa.Gov/ochp/ochpweb.Nsf/content/climate.htm (accessed on 5 September 2012).

35. Pradhan, E.K.; West, K.P.; Katz, J.; LeClerq, S.C.; Khatry, S.K.; Shrestha, S.R. Risk of flood-related mortality in Nepal. Disasters 2007, 31, 57-70.

36. Szpilman, D.; Bierens, J.J.L.M.; Handley, A.J.; Orlowski, J.P. Drowning. N. Engl. J. Med. 2012, 366, 2102-2110.

37. WHO. Injuries and Violence Prevention: Noncommunicable Diseases and Mental Health: Fact Sheet on Drowning; World Health Organization: Geneva, Switzerland, 2003.

38. UNDP. Human Development Report 2007/2008; UNDP: New York, NY, USA, 2007. 
39. Back, E.; Cameron, C. Our Climate, Our Children, Our Responsibility. The Implications of Climate Change for World's Children; UNICEF: New York, NY, USA, 2008.

40. Conserve Africa. Breaking the Vicious Cycle of Poverty and Environmental Degradation in Africa; Poverty and Environment in Africa: An Overview; 2006. Available online: http://www.Conserveafrica.Org.Uk/desertification.html (accessed on 5 September 2012).

41. McMichael, A.J.; Woodruff, R.E.; Hales, S. Climate change and human health: Present and future risks. Lancet 2006, 367, 859-869.

42. Arlappa, N.; Venkaiah, K.; Brahmam, G.N.V. Severe drought and the vitamin a status of rural pre-school children in India. Disasters 2011, 35, 577-586.

43. Meehl, G.A.; Tebaldi, C. More intense, more frequent, and longer lasting heat waves in the 21st century. Science 2004, 305, 994-997.

44. Knowlton, K.; Rotkin-Ellman, M.; King, G.; Margolis, H.G.; Smith, D.; Solomon, G.; Trent, R.; English, P. The 2006 California heat wave: Impacts on hospitalizations and emergency department visits. Environ. Health Perspect. 2008, 117, 61-67.

45. Leonardi, G.S.; Hajat, S.; Kovats, R.S.; Smith, G.E.; Cooper, D.; Gerard, E. Syndromic surveillance use to detect the early effects of heat-waves: An analysis of NHS direct data in England. Soz. Praventivmed. 2006, 51, 194-201.

46. Nitschke, M.; Tucker, G.; Hansen, A.; Williams, S.; Zhang, Y.; Bi, P. Impact of two recent extreme heat episodes on morbidity and mortality in Adelaide, south Australia: A case-series analysis. Environ. Health 2011, 10, doi:10.1186/1476-069X-10-42.

47. Naughton, M.P.; Henderson, A.; Mirabelli, M.C.; Kaiser, R.; Wilhelm, J.L.; Kieszak, S.M.; Rubin, C.H.; McGeehin, M.A. Heat-related mortality during a 1999 heat wave in Chicago. Am. J. Prev. Med. 2002, 22, 221-227.

48. Kovats, R.S.; Hajat, S.; Wilkinson, P. Contrasting patterns of mortality and hospital admissions during hot weather and heat waves in Greater London, UK. Occup. Environ. Med. 2004, 61, 893-898.

49. Basu, R.; Malig, B.; Ostro, B. High ambient temperature and the risk of preterm delivery. Am. J. Epidemiol. 2010, 172, 1108-1117.

50. Strand, L.B.; Barnett, A.G.; Tong, S. Maternal exposure to ambient temperature and the risks of preterm birth and stillbirth in Brisbane, Australia. Am. J. Epidemiol. 2012, 175, 99-107.

51. Hajat, S.; Armstrong, B.; Baccini, M.; Biggeri, A.; Bisanti, L.; Russo, A.; Paldy, A.; Menne, B.; Kosatsky, T. Impact of high temperature on mortality: Is there an added heat wave effect? Epidemiology 2006, 17, 632-638.

52. Gasparrini, A.; Armstrong, B. The impact of heat waves on mortality. Epidemiology 2011, 22, 68-73.

53. Salvante, K.G.; Walzem, R.L.; Williams, T.D. What comes first, the zebra finch or the egg: Temperature-dependent reproductive, physiological and behavioural plasticity in egg-laying zebra finches. J. Exp. Biol. 2007, 210, 1325-1334.

54. Talmage, S.C.; Gobler, C.J. Effects of elevated temperature and carbon dioxide on the growth and survival of larvae and juveniles of three species of northwest Atlantic bivalves. PLoS ONE 2011, 6, doi:10.1371/journal.pone.0026941. 
55. Daily, G. Nature's Services: Societal Dependence on Natural Ecosystems; Island Press: Washington, DC, USA, 1997.

56. IPCC. Climate Change 2007: Synthesis Report; IPCC: Geneva, Switzerland, 2007.

57. Curriero, F.C.; Patz, J.A.; Rose, J.B.; Lele, S. The association between extreme precipitation and waterborne disease outbreaks in the United States, 1948-1994. Am. J. Public Health 2001, 91, 1194-1199.

58. Climate Change Futures-Health, Ecological and Economic Dimensions; The Center for Health and the Global Environment, Harvard Medical School: Boston, MA, USA, 2006.

59. Woodruff, R.; McMichael, A.J. Climate change and human health: All affected, but some more than others. Soc. Alter. 2004, 23, 17-22.

60. Prüss-Üstün, A.; Bos, R.; Gore, F.; Bartram, J. Safer Water Better Health: Costs Benefits and Sustainability of Interventions to Protect and Promote Health; WHO: Geneva, Switzerland, 2008.

61. McMichael, A.J. Impact of climatic and other environmental changes on food production and population health in the coming decades. Proc. Nutr. Soc. 2001, 60, 195-201.

62. Goldbloom, R. Growth failure in infancy. Pediatr. Rev. 1987, 9, 57-61.

63. Department of Agriculture, United States. Nationwide Food Consumption Survey. Continuing Survey of Food Intakes of Individuals: Women 19-50 Years and Their Children 1-5 years, 4 days, 1985; Human Nutrition Information Service: Hyattsville, MD, USA, 1987.

64. Cohen, M.; Tirado, C.; Aberman, N. Impact of Climate Change and Bioenergy on Nutrition; FAO: Rome, Italy, 2008.

65. Sheridan, B. The implications of climate change for children in lower-income countries. Child. Youth Environ. 2008, 18, 71-98.

66. Booth, S.; Zeller, D. Mercury, food webs, and marine mammals: Implications of diet and climate change for human health. Environ. Health Perspect. 2005, 113, 521-526.

67. Noyes, P.D.; McElwee, M.K.; Miller, H.D.; Clark, B.W.; Van Tiem, L.A.; Walcott, K.C.; Erwin, K.N.; Levin, E.D. The toxicology of climate change: Environmental contaminants in a warming world. Environ. Int. 2009, 35, 971-986.

68. Wania, F.; MacKay, D. Tracking the distribution of persistent organic pollutants. Environ. Sci. Technol. 1996, 30, A390-A396.

69. Meyer, T.; Wania, F. Organic contaminant amplification during snowmelt. Water Res. 2008, 42, 1847-1865.

70. Macdonald, R.W.; Mackay, D.; Li, Y.F.; Hickie, B. How will global climate change affect risks from long-range transport of persistent organic pollutants? Human Ecol. Risk Assess. Int. J. 2003, 9, 643-660.

71. Macdonald, R.; Mackay, D.; Hickie, B. Contaminant amplification in the environment. Environ. Sci. Technol. 2002, 36, A456-A462.

72. Brent, R.; Weitzman, M.; Balk, S.; Lanphear, B.; Landrigan, P.; Reigart, R. The vulnerability, sensitivity, and resiliency of the developing embryo, infant, child, and adolescent to the effects of environmental chemicals, drugs, and physical agents as compared to the adult. Pediatrics 2004, 113, 932-1172.

73. Crimmins, E.M.; Finch, C.E. Infection, inflammation, height, and longevity. Proc. Natl. Acad. Sci. USA 2006, 103, 498-503. 
74. Victora, C.; Adair, L.; Fall, C.; Hallal, P.; Martorell, R.; Richter, L. Maternal and child undernutrition: Consequences for adult health and human capital. Lancet 2008, 371, 340-357.

75. WHO. Reducing Environmental Risks for Our Children. In Proceedings of 4th International Conference on Children's Health and the Environment, Vienna, Austria, 10-12 June 2007.

76. Landrigan, P. What's Getting into Our Children? Available online: http://healthychild.org/blog/ comments/whats_getting_into_our_children/ (accessed on 5 September 2012).

77. WHO. Health Environment for Children. Initiating an Alliance for Action; WHO: Geneva, Switzerland, 2002.

78. Cohen, J.T.; Bellinger, D.C.; Shaywitz, B.A. A quantitative analysis of prenatal methyl mercury exposure and cognitive development. Am. J. Prev. Med. 2005, 29, 353-353.

79. UNEP. Inventory of Information Sources on Chemicals: Persistent Organic Pollutants; UNEP: Geneva, Switzerland, 1999.

80. UNEP. Regional Workshop on the Implementation of the Stockholm Convention and Synergies with Others Related Agreements; UNEP: Cairo, Egypt, 2005.

81. Warner, K.; Afifi, T.; Dun, O.; Stal, M.; Schmidl, S. Human Security, Climate Change, and Environmentally Induced Migration; Hellenic Foundation for European and Foreign Policy (ELIAMEP): Athens, Greece, 2008.

82. Gemenne, F. Climate-induced population displacements in a $4{ }^{\circ} \mathrm{C}+$ world. Philos. Transact. A Math. Phys. Eng. Sci. 2011, 369, 182-195.

83. UN. Climate Change, Human Rights and Forced Human Displacement: Case Studies as Indicators of Durable Solutions. In The 60th Anniversary of the Universal Declaration of Human Rights and International Human Rights Day; UN: Canberra, Australia, 2008.

84. Kristiansen, M.; Mygind, A.; Krasnik, A. Health effects of migration. Dan. Med. Bull. 2007, 54, 46-47.

85. Pronczuk, J. Where the Child Learns. In Children's Health and the Environment-A Global Perspective: A Resource Manual for the Health Sector; Pronczuk-Garbino, J., Ed.; WHO: Geneva, Switzerland, 2005.

86. Gerba, C.P.; Rose, J.B.; Haas, C.N. Sensitive populations: Who is at the greatest risk? Int. J. Food Microbiol. 1996, 30, 113-123.

87. IPCC. Climate Change 2007: Impacts, Adaptation and Vulnerability. Contribution of Working Group II to the Fourth Assessment Report of the Intergovernmental Panel on Climate Change; Cambridge University Press: Cambridge, UK, 2007; pp. 391-431.

88. Loevinsohn, M.E. Climatic warming and increased malaria incidence in Rwanda. Lancet 1994, 343, 714-718.

89. Rogers, D.; Randolph, S. The global spread of malaria in a future, warmer world. Science 2000, 289, 1763-1765.

90. Ishak, H.; Miyagi, I.; Toma, T.; Kamimura, K. Breeding habitats of Aedes aegypti (L) and Aedes. albopictus (Skuse) in villages of Barru, South Sulawesi, Indonesia. Southeast Asian J. Trop. Med. Public Health 1997, 28, 844-850.

91. Snow, R.; Craig, M.; Deichmann, U.; Marsh, K. Estimating mortality, morbidity and disability due to malaria among Africa's non-pregnant population. Bull. World Health Organ. 1999, 77, 624-640. 
92. WHO. World Malaria Report 2005; WHO: Geneva, Switzerland, 2005.

93. Gilca, R.; Deceuninck, G.; De Serres, G.; Boulianne, N.; Sauvageau, C.; Quach, C.; Boucher, F.D.; Skowronski, D.M. Effectiveness of pandemic H1N1 vaccine against influenza-related hospitalization in children. Pediatrics 2011, 128, e1084-e1091.

94. LaForce, F.; Konde, K.; Viviani, S.; Préziosi, M. The Meningitis vaccine project. Vaccine 2007, 25, A97-A100.

95. Baena-Cagnani, C.; Badellino, H. Diagnosis of allergy and asthma in childhood. Curr. Allergy Asthma Rep. 2011, 11, 71-77.

96. Eder, W.; Ege, M.J.; von Mutius, E. The asthma epidemic. N. Engl. J. Med. 2006, 355, 2226-2235.

97. Sheffield, P.E.; Weinberger, K.R.; Kinney, P.L. Climate change, aeroallergens, and pediatric allergic disease. Mt. Sinai J. Med. 2011, 78, 78-84.

98. Singer, B.D.; Ziska, L.H.; Frenz, D.A.; Gebhard, D.E.; Straka, J.G. Increasing Amb a 1 content in common ragweed (Ambrosia artemisiifolia) pollen as a function of rising atmospheric $\mathrm{CO}_{2}$ concentration. Func. Plant Biol. 2005, 32, 667-670.

99. Wayne, P.; Foster, S.; Connolly, J.; Bazzaz, F.; Epstein, P. Production of allergenic pollen by ragweed (Ambrosia artemisiifolia L.) is increased in $\mathrm{CO}_{2}$-enriched atmospheres. Ann. Allergy Asthma Immunol. 2002, 88, 279-282.

100. Wolf, J.; O’Neill, N.R.; Rogers, C.A.; Muilenberg, M.L.; Ziska, L.H. Elevated atmospheric carbon dioxide concentrations amplify alternaria alternata sporulation and total antigen production. Environ. Health Perspect. 2010, 118, 1223-1228.

101. Ziska, L.H.; Gebhard, D.E.; Frenz, D.A.; Faulkner, S.; Singer, B.D.; Straka, J.G. Cities as Harbingers of climate change: Common ragweed, urbanization, and public health. J. Allergy Clin. Immunol. 2003, 111, 290-295.

102. Shea, K.M.; Truckner, R.T.; Weber, R.W.; Peden, D.B. Climate change and allergic disease. J. Allergy Clin. Immunol. 2008, 122, 443-453.

103. Beggs, P.J.; Bambrick, H.J. Is the global rise of asthma an early impact of anthropogenic climate change? Environ. Health Perspect. 2005, 113, 915-919.

104. WHO. Reducing Risks and Promoting Healthy Life; WHO: Geneva, Switzerland, 2002.

105. Constructing Change: Accelerating Energy Efficiency in India's Building Market; Administrative Staff College of India and Natural Resources Defense Council: Hyderabad, India, 2012.

106. Zimmerman, R.; Faris, C. Climate change mitigation and adaptation in North American cities. Curr. Opin. Environ. Sustain. 2011, 3, 181-187.

107. Bergeron, M.; Bahr, R.; Bärtsch, P.; Bourdon, L.; Calbet, J.; Carlsen, K.; Castagna, O.; González-Alonso, J.; Lundby, C.; Maughan, R.; et al. International Olympic Committee consensus statement on thermoregulatory and altitude challenges for high-level athletes. $\mathrm{Br}$. $\mathrm{J}$. Sports Med. 2012, 46, 770-779.

108. Huq, S.; Reid, H. Community-Based Adaptation: A Vital Approach to the Threat Climate Change Poses to the Poor; International Institute for Environment and Development: London, UK, 2007.

109. Berrang-Ford, L.; Ford, J.D.; Paterson, J. Are we adapting to climate change? Glob. Environ. Change 2011, 21, 25-33. 
110. IFRC. World Disasters Report 2007, Focus on Discrimination; IFRC: London, UK, 2007.

111. Goenjian, A.K.; Walling, D.; Steinberg, A.M.; Karayan, I.; Najarian, L.M.; Pynoos, R. A prospective study of posttraumatic stress and depressive reactions among treated and untreated adolescents 5 years after a catastrophic disaster. Am. J. Psychiatry 2005, 162, 2302-2308.

112. Wolmer, L.; Laor, N.; Dedeoglu, C.; Siev, J.; Yazgan, Y. Teacher-mediated intervention after disaster: A controlled three-year follow-up of children's functioning. J. Child Psychol. Psychiatry 2005, 46, 1161-1168.

113. Gruen, R.L.; Campbell, E.G.; Blumenthal, D. Public roles of US physicians. JAMA 2006, 296, 2467-2475.

114. Voelker, R. Climate change puts children in jeopardy. JAMA 2009, 301, 2197-2199.

115. Hajat, S.; Armstrong, B.G.; Nelson, G.; Wilkinson, P. Mortality displacement of heat-related deaths: A comparison of Delhi, São Paulo, and London. Epidemiology 2005, 16, 613-620.

116. Hutter, H.-P.; Moshammer, H.; Wallner, P.; Leitner, B.; Kundi, M. Heatwaves in Vienna: Effects on mortality. Wien. Klin. Wochenschr. 2007, 119, 223-227.

117. Green, R.; Basu, R.; Malig, B.; Broadwin, R.; Kim, J.; Ostro, B. The effect of temperature on hospital admissions in nine California Counties. Int. J. Public Health 2010, 55, 113-121.

118. McConnell, R.; Berhane, K.; Gilliland, F.; London, S.J.; Islam, T.; Gauderman, W.J.; Avol, E.; Margolis, H.G.; Peters, J.M. Asthma in exercising children exposed to ozone: A cohort study. Lancet 2002, 359, 386-391.

119. Bond, G. Tackling Student Absenteeism: Research Findings and Recommendations for School and Local Communities; Hume Whittlesea: Broadmeadows, Australia, 2004.

120. Average Rates of Student Attendance at Primary and Secondary School (Percentage); Department of Education and Early Childhood Development: Melbourne, Australia, 2007.

121. UNICEF. Statistics. South Africa. Education; UNICEF: New York, NY, USA, 2010.

122. Checkley, W.; Epstein, L.D.; Gilman, R.H.; Figueroa, D.; Cama, R.I.; Patz, J.A.; Black, R.E. Effects of El Niño and ambient temperature on hospital admissions for diarrhoeal diseases in Peruvian children. Lancet 2000, 355, 442-450.

123. Grech, V.; Balzan, M.; Asciak, R.; Buhagiar, A. Seasonal variations in hospital admissions for asthma in Malta. J. Asthma 2002, 39, 263-268.

124. Weinbruch, S.; Dirsch, T.; Ebert, M.; Hofmann, H.; Kandler, K. Dust exposure in indoor climbing halls. J. Environ. Monit. 2008, 10, 648-654.

125. Casa, D.; Armstrong, L.; Kenny, G.; O’Connor, F.; Huggins, R. Exertional heat stroke: New concepts regarding cause and care. Curr. Med. Sports Rep. 2012, 11, 115-123.

126. Ostro, B.; Rauch, S.; Green, R.; Malig, B.; Basu, R. The effects of temperature and use of air conditioning on hospitalizations. Am. J. Epidemiol. 2010, 172, 1053-1061.

127. Bandyopadhyay, S.; Kanji, S.; Wang, L. The impact of rainfall and temperature variation on diarrheal prevalence in Sub-Saharan Africa. Appl. Geogr. 2012, 33, 63-72.

128. Gouveia, N.; Hajat, S.; Armstrong, B. Socioeconomic differentials in the temperature-Mortality relationship in São Paulo, Brazil. Int. J. Epidemiol. 2003, 32, 390-397.

129. Lam, L.T. The association between climatic factors and childhood illnesses presented to hospital emergency among young children. Int. J. Environ. Health Res. 2007, 17, 1-8. 
130. Huang, C.; Barnett, A.G.; Wang, X.; Vaneckova, P.; FitzGerald, G.; Tong, S. Projecting future heat-related mortality under climate change scenarios: A systematic review. Environ. Health Perspect. 2011, 119, 1681-1690.

131. Lopez, A.; Mathers, C.; Ezzati, M.; Jamison, D.; Murray, C. Global Burden of Disease and Risk Factors; Oxford Unversity Press: Oxford, UK, 2006.

132. WHO. Climate Change and Human Health-Risks and Responses. Summary; WHO: Geneva, Switzerland, 2003.

133. Khady, D. Governance and natural disasters: Addressing flooding in Saint louis, Senegal. Environ. Urban. 2007, 19, 552-562.

134. Zhao, Z.; Zhang, Z.; Wang, Z.; Ferm, M.; Liang, Y.; Norbäck, D. Asthmatic symptoms among pupils in relation to winter indoor and outdoor air pollution in schools in Taiyuan, China. Environ. Health Perspect. 2007, 116, 90-97.

135. Zhou, X.-N.; Yang, G.-J.; Yang, K.; Wang, X.-H.; Hong, Q.-B.; Sun, L.-P.; Malone, J.B.; Kristensen, T.K.; Bergquist, N.R.; Utzinger, J. Potential impact of climate change on schistosomiasis transmission in China. Am. J. Trop. Med. Hyg. 2008, 78, 188-194.

136. Gosling, S.; McGregor, G.; Lowe, J. Climate change and heat-related mortality in six cities part 2: Climate model evaluation and projected impacts from changes in the mean and variability of temperature with climate change. Int. J. Biometeorol. 2009, 53, 31-51.

137. Jackson, J.; Yost, M.; Karr, C.; Fitzpatrick, C.; Lamb, B.; Chung, S.; Chen, J.; Avise, J.; Rosenblatt, R.; Fenske, R. Public health impacts of climate change in Washington State: Projected mortality risks due to heat events and air pollution. Climatic Change 2010, 102, 159-186.

138. UNICEF. The State of the World's Children; United Nations Children's Fund: New York, NY, USA, 2006.

(C) 2012 by the authors; licensee MDPI, Basel, Switzerland. This article is an open access article distributed under the terms and conditions of the Creative Commons Attribution license (http://creativecommons.org/licenses/by/3.0/). 